Apidologie, 1988, 19 (1), 97-102

\title{
REDISCOVERY OF APIS VECHTI (MAA, 1953): THE SABAN HONEY BEE
}

\author{
Salim TingeK *, Makhdzir MARdan **(1), Thomas E. Rinderer ***, \\ Nikolaus KoEniger **** and Gudrun Koeniger **** \\ * Agricultural Research Station, Tenom, Sabah, Malaysia \\ ** Department of Plant Protection, University Pertanian Malaysia \\ 43400 UPM Serdang, Selangor, Malaysia \\ *** U.S. Department of Agriculture, Agricultural Research Service, \\ Honey-Bee Breeding, Genetics, and Physiology Laboratory \\ 1157 Ben Hur Road, Baton Rouge, Louisiana 70820, U.S.A. \\ **** Institut für Bienenkunde (Polytechn. Ges.) ; J.W. Goethe Universität, \\ Frankfurt am Main, Karl-von-Frisch Weg 2, D-6370 Oberursel, West Germany
}

\section{SUMMARY}

The species Apis vechti (MAA, 1953), the Saban honey bee, is recognized as a valid species. Additional to the description of MAA (1953) species-specific characters associated with the endophallus, hind leg tibial hair of the drone and worker bee fore-wing venation are described.

\section{INTRODUCTION}

We recently investigated the origins of a body color variation present in the populations of honey bees in Sabah that occupy multiple comb nests in cavities. Sabah is the northeastern most area of the island of Borneo. Some of the cavity nesting honey bees of the area are primarily black; others are uniformly rufous.

It quickly became apparent that the rufous bees had a variety of characteristics which showed that they were members of a separate species. MAA (1953) studied workers of this species, and based on worker bee morphology, described and named them Sigmatapis vechti. RUTTNER (1988) has argued that Maa's subgenera in the genus Apis are unnecessary. The subgenus Sigmatapis is considered to be the species Apis cerana. MaA (1953) has provided the Saban honey bee with its species name, Apis vechti, and has provided a clear

(1) Address for reprint request. 
species description. In doing so, MAA divided the species into two subspecies; Apis vechti vechti and Apis vechti linda. We do not have evidence to support the interpretation that the species has sufficient variation to warrant the designation of subspecies.

In support of species comparisons we designate a colony labeled as G21 as a standard of reference for our descriptions. Workers from G21 and workers from six additional colonies are being deposited in the collections of U.S. National Museum, Washington D.C.

\section{Species-specific Characteristics}

The si paret for recognizing species of animals is documenting reproductive isolation, especially when sibling species are sympatric. Apis vechti is sympatric in North Borneo with Apis cerana, Apis florea, and Apis dorsata. Of these three, it is most similar to Apis cerana because of its use of nests having multiple combs constructed in cavities. Apis vechti is reproductively isolated from Apis cerana by the segregation of the daily temporal patterns of reproductive activity (KoENIGER et al., 1988). Complete reproductive isolation is insured by the shape of the Apis vechti endophallus (Fig. 1). A stage 9
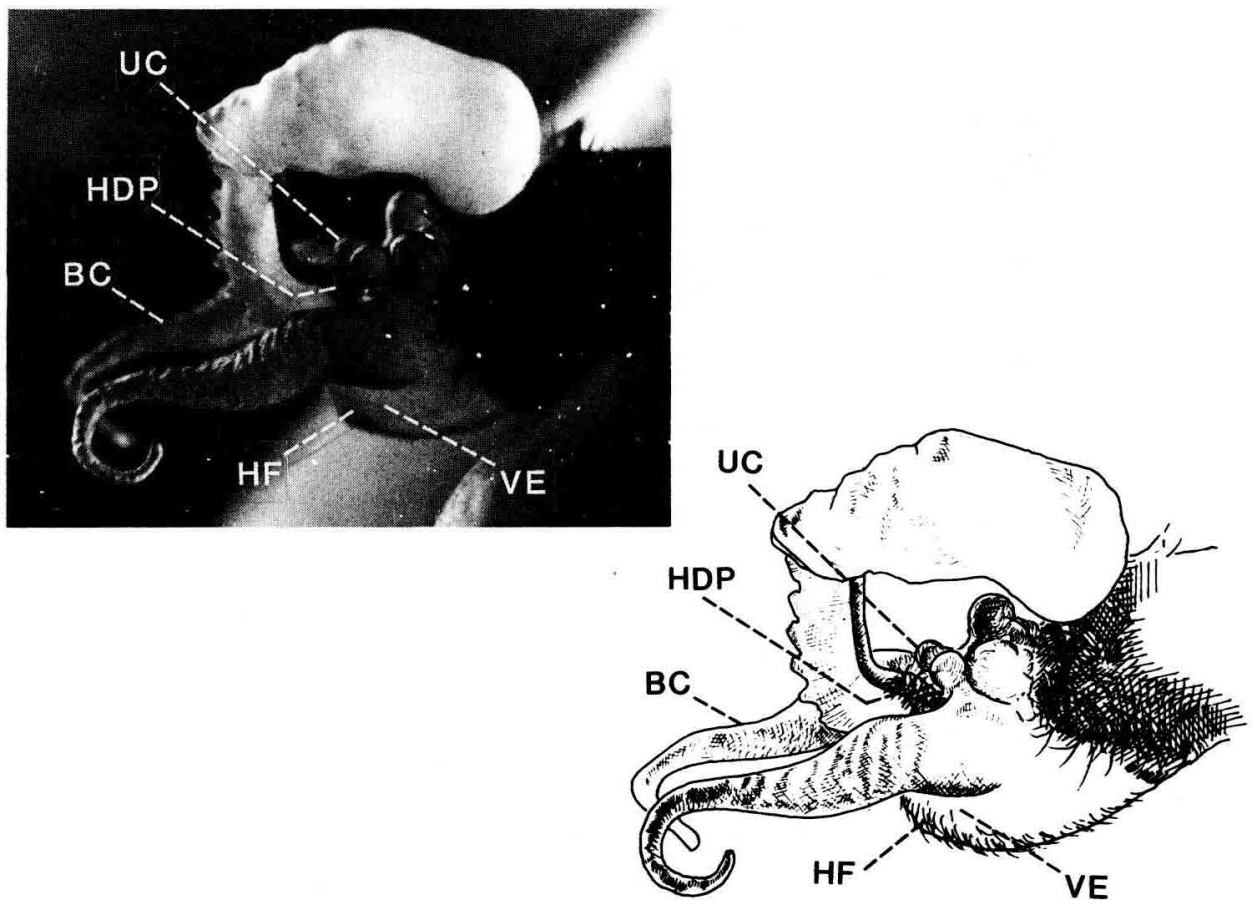

FIG. 1. - Photograph and drawing of the Apis vechti endophallus

$\mathrm{UC}=$ upper cornua, $\mathrm{HDP}=$ hairy dorsal triangular plate, $\mathrm{BC}=$ bursal cornua, $\mathrm{HF}=$ hairy field, $\mathrm{VE}=$ vestibulum of endophallus. 
A

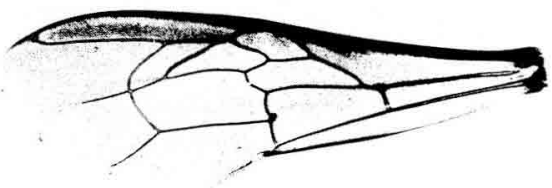

C

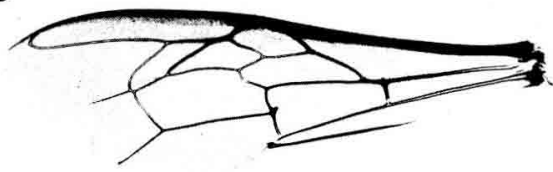

B

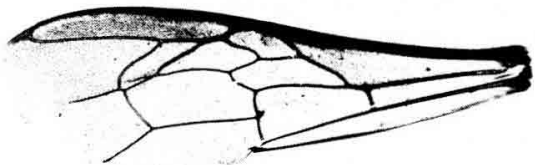

D

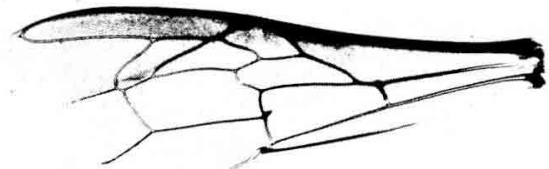

Fig. 2. - The forewings of 4 workers of Apis vechti showing much of the cubital index (CI) variation $\mathrm{A}, \mathrm{CI}=24.74 ; \mathrm{B}, \mathrm{CI}=8.40 ; \mathrm{C}, \mathrm{CI}=8.70 ; \mathrm{D}, \mathrm{CI}=4.51$.
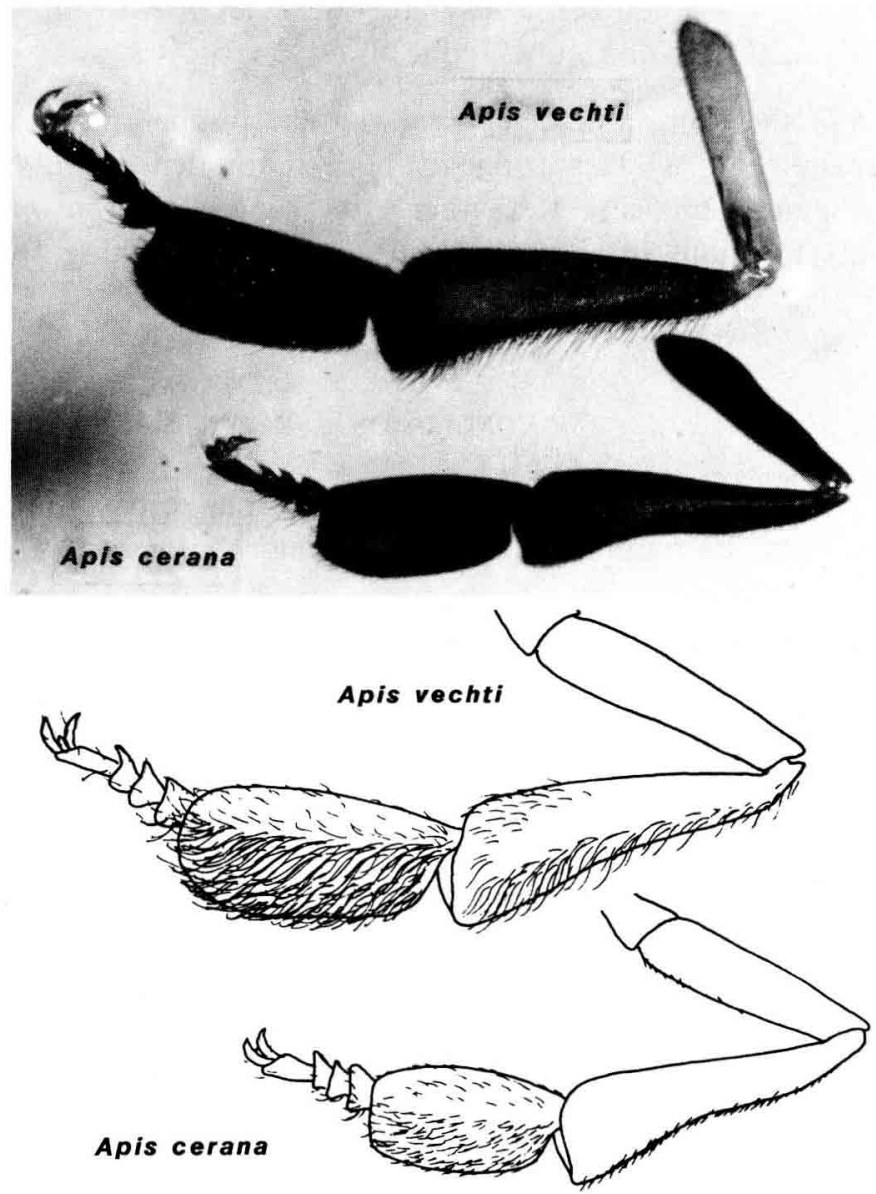

Fig 3. - The hindleg of an Apis vechti drone compared to the hindleg of an Apis ccrana drone showing the hairy fringe on the posterior margin of the femur. 
eversion (Woyke, 1958 ; RUTTNER et al., 1973) is characterized by 2 exceptionally long anteriorly-curling bursal cornua, two bulbous upper cornua on either side of the vestibulum ( $A$. cerana has three pointed upper cornua on each side) and a proportionally large and markedly hairy dorsal triangular plate and hairy field on the vestibulum. Collectively, these characteristics of the Apis vechti endophallus constitute si paret evidence that Apis vechti is a true biological species (See RUTTNER, 1988 for description of the endophalli of the other species and discussion of the species-specific value for honey bees of the structure of the drone endophallus).

The wing venation of Apis vechti workers is also exceptional (Fig. 2). Most notably, the cubital index is both quite large and quite varied $(\overline{\mathrm{X}}=7.455 \pm$ S.D. $3.04 ;$ range $=3.53-24.74 ; \mathrm{N}=80)$. In this respect the wing venation of Apis vechti is more similar to that of Apis dorsata than it is to the other species. Cubital cell 3 appears « distorted » with the distal abcissa of vein $\mathbf{M}$ (segment $\mathbf{b}$ ) being quite reduced.

The tibia of the drone's hind leg bears an exceptionally hairy fringe on its posterior margin (Fig. 3). This fringe is both more dense and composed of coarser hairs than is the case for either Apis cerana or Apis mellifera. The fringe probably functions in a specific way to facilitate mating.

\section{CONCLUSION}

Apis vechti (MAA, 1953) is a valid species. Further studies are underway to more fully describe its natural history and its morphology. The assurance of the survival of Apis vechti should be given highest priority by investigators. The size of the population should be described and known to be acceptably large before destructive collections are made from large numbers of colonies.

Received for publication in March 1988. Accepted for publication in March 1988.

\section{ACKNOWLEDGEMENTS}

In cooperation with Louisiana Agricultural Experiment Station. Sincere appreciation is expressed to Gerard Perrone for his work in preparing the figures, and G. Lorraine Davis for dissections. We thank F. RUTTNER and H.V. DALY for suggestions concerning the manuscript. 


\title{
RÉSUMÉ
}

\author{
REDÉCOUVERTE D'APIS VECHTI (MAA, 1953) : L'ABEILLE SABAHIENNE
}

\begin{abstract}
A Sabah (nord-est de Bornéo) a été découverte une espèce d'abeille qui se différencie nettement d'Apis cerana. Ces abeilles construisent dans des cavités plusieurs rayons parallèles. Les ouvrières de cette espèce sont nettement plus grosses que celles d'Apis cerana de Bornéo. La couleur jaune de l'abdomen et surtout les pattes jaunes différencient clairement ces abeilles des autres espèces. Par sa couleur et sa taille, cette abeille correspond à Stigmatapis vechti décrite par MAA (1953) à Bornéo également. Le classement systématique de l'abeille en de très nombreux genres et espèces par MAA, qui ne reposait que sur la description de quelques spécimens provenant de musées, n'est généralement pas reconnue. Il faut donc proposer comme nom légitime Apis vechti (MAA, 1953). Grâce à la redécouverte de cette espèce d'abeille, il a été possible de prouver qu'Apis vechti est une espèce bien définie.
\end{abstract}

\section{ZUSAMMENFASSUNG}

\section{WIEDERENTDECKUNG VON APIS VECHTI (MAA, 1953) : DER SABAHENSISCHEN HONIGBIENE}

In Sabah (Nordost-Borneo) wurde eine Bienenart gefunden, die sich deutlich von Apis cerana unterscheidet. Die Bienenvölker leben in Höhlen mit mehreren parallelen Waben. Die Arbeiterinnen dieser Art sind deutlich größer als Apis cerana aus Borneo. Die gelbe Farbe des Abdomens und vor allem die gelben Beine unterscheiden die Bienen deutlich von allen anderen Bienenarten. Auf Grund der Farbe und der Größenmaße ist eine Übereinstimmung der Biene mit der von MAA (1953) auch aus Borneo beschriebenen Sigmatapis vechti festzustellen. Die systematische Einteilung der Honigbiene in sehr viele Gattungen und Arten von MAA, die ausschlieBlich auf der Beschreibung weniger Exemplare aus Museen beruht, ist nicht allgemein anerkannt. So muB als gültiger Name für die Art Apis vechti (MAA, 1953) vorgeschlagen werden. Über die Wiederentdeckung dieser Honigbienenart hinaus, gelang der Nachweis, daß Apis vechti eine eigene gut definierte Art ist.

\section{REFERENCES}

KoENIGer N. et al., 1988. - Reproductive isolation by different time of drone flight between Apis cerana (Fabricius, 1793) and Apis vechti (Maa, 1953). Apidologie, 19 (1), 103-106.

MAA T., 1953. - An inquiry into the systematics of the tribus Apidini or honeybees (Hym.). Treubia, 21 (3), 525-640.

Rutrner F., 1988. - Biogeography and Taxonomy of Honeybees. Berlin, Springer Verlag, 284 p.

Ruttner F., Woyke J. \& Koeniger N., 1973. - Reproduction in Apis cerana 2. Reproductive organs and natural insemination. J. Apic. Res., 12 (1), 21-34.

WOYke J., RUtTNER H., 1958. - An anatomical study on the mating process in the honeybee. Bee World, 39 (1), 3-18. 